\section{OCCURRENCE OF THREE WESTERN GHATS ELEMENTS IN DRY EVERGREEN FOREST OF Gingee Hills, EAStern Ghats of TAMIL NADU, INDIA}

\author{
N. Balachandran ${ }^{1}$, K. Rajendiran ${ }^{2} \&$ W.F. Gastmans ${ }^{3}$ \\ ${ }^{1,2}$ Kanchi Mamuniver Centre for Post-Graduate Studies, Lawspet, \\ Puducherry 605008, India \\ ${ }^{3}$ AURO Herbarium, Shakti, Auroville, Tamilnadu 605101, India \\ ${ }^{1}$ nbala_plant@yahoo.co.in (corresponding author), \\ ${ }^{2}$ rajeworks@yahoo.com, ${ }^{3}$ walter@auroville.org
}

The tropical dry evergreen forest (TDEF) is a unique forest type found along the coromandel coast of India which remains only in fragmented form now. It is distributed between Vishakhapatnam, Andhra Pradesh in the north and Point Calimer, Tamil Nadu in the south; along the east coast of India it is long-drawn-out from the coast upto the hills on the west to about $55 \mathrm{~km}$. The concept of TDEF as described by Champion \& Seth (1968) has under gone changes. One such proposal is to include 'Albizia amara community', based on the wide distribution of the species across the coastal plains, by Meher-Homji (1974). Sprangers \& Balasubramanian (1978) had suggested Drypetes-Strychnos-Memecylon association with the occurrence of species dominance in this forest type but Daniel et al. (2008) expressed this vegetation as 'a misnomer'.

The main objective of the present work was to study the plant diversity from the existing forests, sacred groves, remnant vegetation and hillocks as a belt extending through Kancheepuram, Villupuram and Cuddalore districts of Tamil Nadu and Union Territory of Pondicherry, coromandel coast of southern India. Besides the aim of this work was also to record the diversity inclination of the core TDEF elements from the coast to the hills as well as from north to south across different geographical dimensions such as altitude, latitude and longitude with respect to climatic gradients.

In this perspective, an intensive survey carried out at Gangevaram and Pakkam Malai Reserve Forest (RF), Gingee Hills of Villupuram District, Tamil Nadu resulted in the collection of three interesting species, viz., Diospyros affinis, Drypetes porteri and Premna wightiana, which had earlier not been recorded from the Eastern Ghats (Matthew 1983; Henry et al. 1987; Saxena \& Brahman 1994; Pullaiah \& Moulali 1997; Vijayasankar et al. 2012). All the specimens are deposited at AURO Herbarium (AURO!), Auroville. The species have been enumerated with detailed description, phenology, ecology, notes and conservation measures along with plates and the distribution maps to facilitate their easy identification.
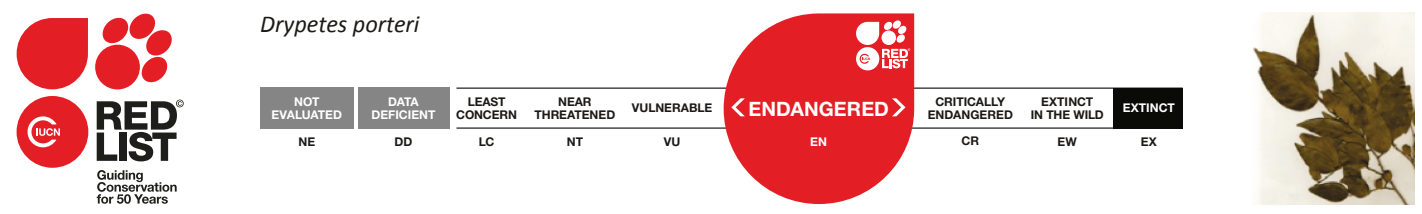

DOI: http://dx.doi.org/10.11609/jott.2433.7.14.8177-8181

Editor: Ravi Prasad Rao, Sri Krishnadevaraya University, Anantpur, India.

Date of publication: 26 November 2015 (online \& print)

Manuscript details: Ms \# 03831 | Received 29 October 2013 | Final received 20 March 2015 | Finally accepted 02 November 2015

Citation: Balachandran, N, K. Rajendiran \& W.F. Gastmans (2015) Occurrence of three Western Ghats elements in dry evergreen forest of Gingee Hills, Eastern Ghats of Tamil Nadu, India. Journal of Threatened Taxa 7(14): 8177-8181; http://dx.doi.org/10.11609/jott.2433.7.14.8177-8181

Copyright: (C) Balachandran et al. 2015. Creative Commons Attribution 4.0 International License. JoTT allows unrestricted use of this article in any medium, reproduction and distribution by providing adequate credit to the authors and the source of publication.

Funding: None.

Conflict of Interest: The authors declare no competing interests.

Acknowledgements: The authors are thankful to Dr. V. Ramasamy, Head of the Department of Botany, KMCPGS for the constant encouragement and providing facilities; Dr. K. Ravikumar, Assistant Director, FRLHT for the critical comments on this manuscript; European Commission for the financial assistance; Mr. Paul Blanchflower, Mr. Jaap den Hollander and Mr. Saravanan were our survey team members during the field survey; Mrs. Sathya Sangeetha developed the distribution map and Mrs. Suganthi for designing the plates. 


\section{Ebenaceae}

\section{Diospyros affinis}

Thwaites, Enum. PI. Zeyl. 179. 1860; C.B. Clarke in Hook. f. FI. Brit. India 3: 566. 1882; Gamble, Fl. Madras 2: 773.1957 (Repr.); Kosterm. in Dassan. and Fosberg, Revis. Handb. Fl. Ceylon 3: 47. 1981; V. Singh, Monogr. Indian Diospyros 37. 2005. (Image 1).

Evergreen, dioecious trees, up to $8 \mathrm{~m}$ high; branchlets thinly puberulous when young. Leaves alternate, ellipticoblong to oblanceolate, $3.5-11.5 \times 1.5-4.5 \mathrm{~cm}$, thinly coriaceous, glabrous on maturity; lateral nerves 7-12 pairs, reticulating nerves anastomosing. Female flowers solitary or in $2-5 \mathrm{~cm}$ long racemes, axillary or terminal. Calyx 6-8mm long, hairy on both sides, 4-lobed. Corolla 8-10 mm long, tubular, hairy outside. Ovary adpressed hairy. Berries globose-cylindrical, up to $2.2 \times 1.8 \mathrm{~cm}$ across, apiculate, densely appressed hairy when young, glabrulous with age, fruiting calyx enlarged, strongly reflexed, deeply lobed, with slight internal elevated rim; lobes foliaceous, distinctly veined outside, densely pubescent on both sides; fruiting pedicels 5 $-6 \mathrm{~mm}$ long, pubescent, thickened and articulated with calyx base. Seeds 4.

Specimen examined: 5643, 18.ix.1996, Pakkamalai RF, Gingee (in fruit), 360m, coll. Jaap den Hollander, Paul Blanchflower \& Walter F. Gastmans; F6809, 02.x.1998, Pakkamalai RF, Gingee (in female flower), 270m, coll. Jaap den Hollander, Paul Blanchflower \& Walter F. Gastmans; 12360, 10.ii.2006, Gingee (in fruit), 240m, coll. Walter F. Gastmans \& N. Balachandran.

Flowering \& Fruiting: June-October, at Western Ghats; September-March in Eastern Ghats.

Ecology: Usually scattered along seasonal streambeds in dry deciduous, dry evergreen or moist deciduous forests, up to $1000 \mathrm{~m}$. This species is found in association with Atalantia monophylla, Grewia flavescens, Gardenia gummifera, Spondias pinnata and Manilkara roxburghiana.

Distribution: Native to southern peninsular India and Sri Lanka. In India, this species was earlier known from the hills of Tirunelveli (Tamil Nadu). Singh (2005) reported this species from Karnataka. The present report shows the distinct distribution of the species in Western Ghats and an isolated hill range of Eastern Ghats (Fig. 1).

Conservation measures: A population of around 35 plants at Pakkam Malai RF and only two mature individuals from Gingee Hills were observed. Seeds were collected; seedlings raised and planted about 120 individuals in different communities of Auroville which are performing well.

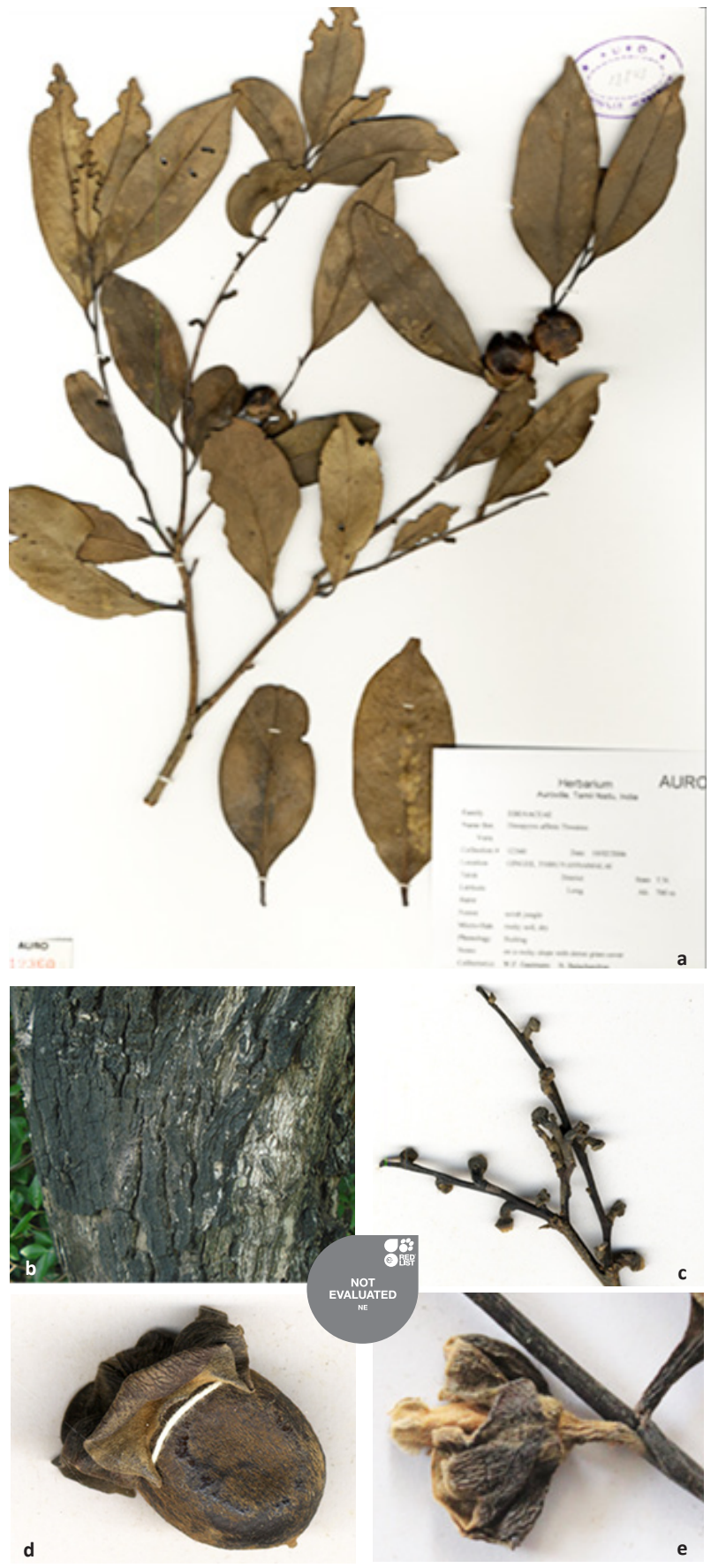

Image 1. Diospyros affinis

a - Fruiting branch; b - Bark; c - Raceme; d - Fruit; e - Flower.

\section{Putranjivaceae}

\section{Drypetes porteri}

(Gamble) Pax \& K. Hoffm. in Engler, Pflanzenr., IV, 147, 15: 268. 1922; Chandrab. in A.N. Henry et al., Fl. Tamil Nadu, Anal. 2: 226.1987; Chakrab. et al., J. Econ. Taxon. Bot. 21: 271, figs. 1-8. 1997; N.P. Balakr. \& Chakrab. Fam. Euphorb. India: 333. 2007; Chakrab. \& N.P. Balakr. in N.P. Balakr. et al., Fl. India 23: 401. 2012. Hemicyclia porteri 


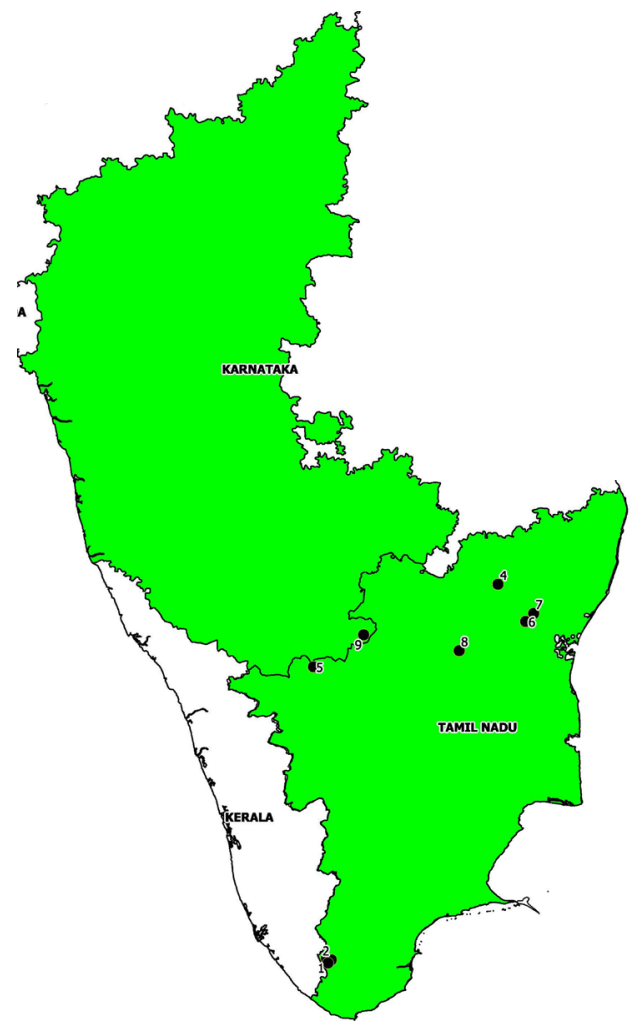

\begin{tabular}{|l|l|l|l|l|}
\hline SI. No & State & District & Location & Altitude (m) \\
\hline 1 & Tamilnadu & Tirunelveli & Ambasamudram & 586 \\
\hline 2 & Tamilnadu & Tirunelveli & Servalar tank & 236 \\
\hline 3 & Tamilnadu & Tirunelveli & Karayar tank & 319 \\
\hline 4 & Tamilnadu & Tiruvannamalai & Mulakkadu R.F. & 827 \\
\hline 5 & Tamilnadu & Coimbatore & Dimbam-Kollegal road & 961 \\
\hline 6 & Tamilnadu & Villupuram & Pakkamalai R.F & 360 \\
\hline 7 & Tamilnadu & Villupuram & Gingee hills & 110 \\
\hline
\end{tabular}

Figure. 1. Distribution of Diosypros affinis

Gamble, Hooker's Icon. PI. 28: t. 2701. 1901 \& FI. Madras 1300. 1925. (Image 2).

Shrub-trees, 6-9 m tall; branchlets brown or greyish, terete, 1-4 $\mathrm{mm}$ thick, pubescent when young, soon glabrous. Leaves alternate, elliptic-obovate or ellipticoblong, 4-9 x 1.5-5 cm, pale greenish or blackish when dry, entire, obtuse (retuse) or acute to acuminate (acumen up to $1 \mathrm{~cm}$ long) at apex, peninnerved; midnerve prominent, lateral nerves 5-7 pairs, prominent on both surfaces, stipules small, caducous; petioles up to $1 \mathrm{~cm}$ long, pubescent to glabrous. Inflorescence axillary; pedicels 5-10 mm long, puberulous. Berries globose, $1.5 \mathrm{~cm}$ across, with dense golden-rufus stellate - pubescent hairs, discoid gland prominent at base, style short, persistent with fruit. Seed 1-2.

Specimen examined: 3324, 29.vi.2001, Tamil Nadu, Gingee, Pakkamalai RF, Gangevaram (in fruit), 350m, coll. Paul Blanchflower.

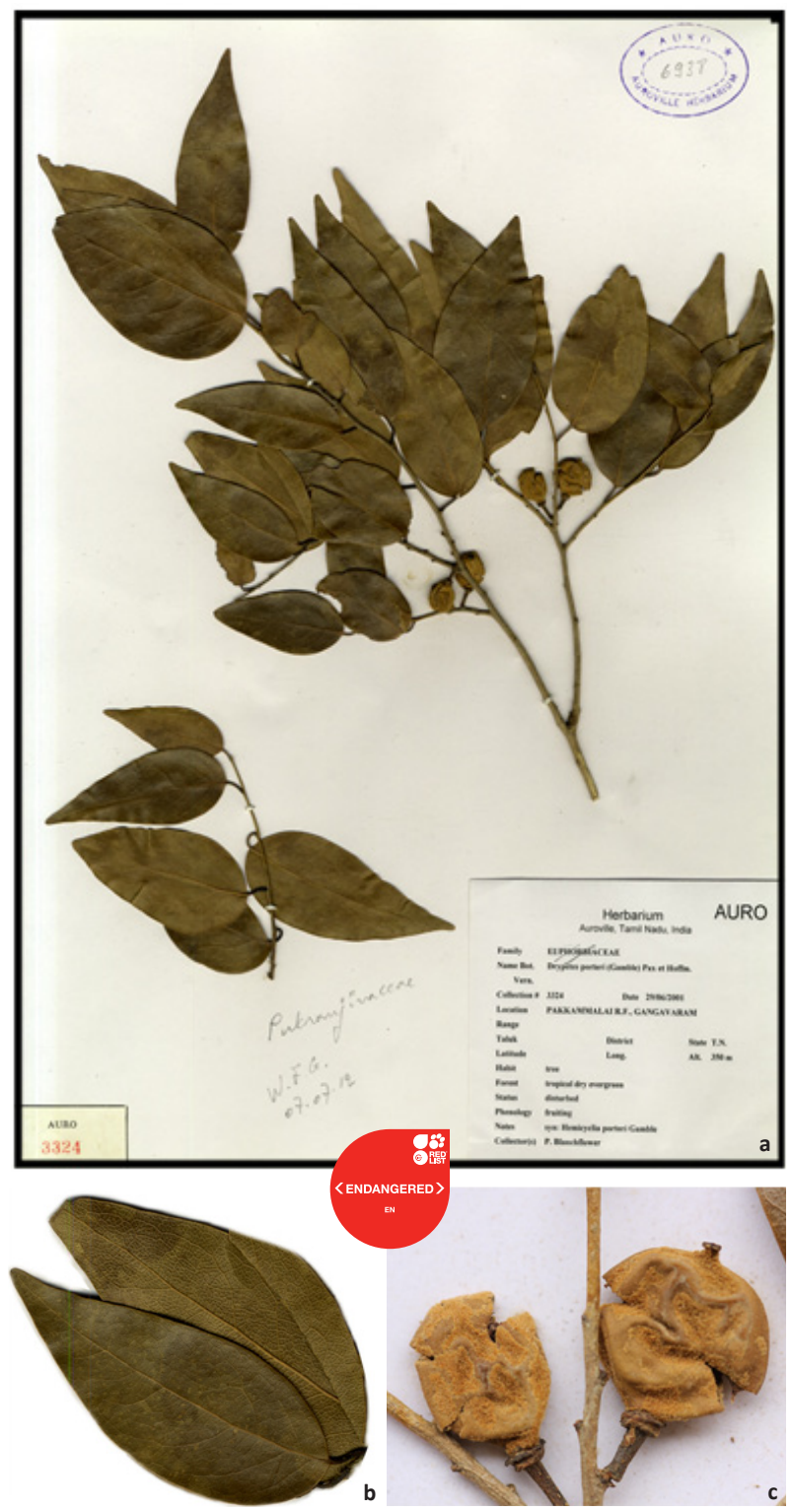

Image 2. Drypetes porteri

a - Fruiting Branch; b - Leaves; c - Fruit

Flowering \& Fruiting: March-July.

Ecology: Very rare in primary forests, often near streams.

Distribution: Endemic to India, known only from Tirunelveli District, southern Western Ghats of Tamil Nadu (Ahmedullah \& Nayar 1986) at 600-1800 m altitude. The present study reports its extended distribution in southern part of Eastern Ghats (Fig. 2).

Notes: There are about 50 mature individuals in two fragmented populations within less than $5 \mathrm{~km}^{2}$ at Agasthiyamalai and adjoining areas of Tamil Nadu, southern Western Ghats, India. In the present study, there are seven trees found along the stream side in the valley. 


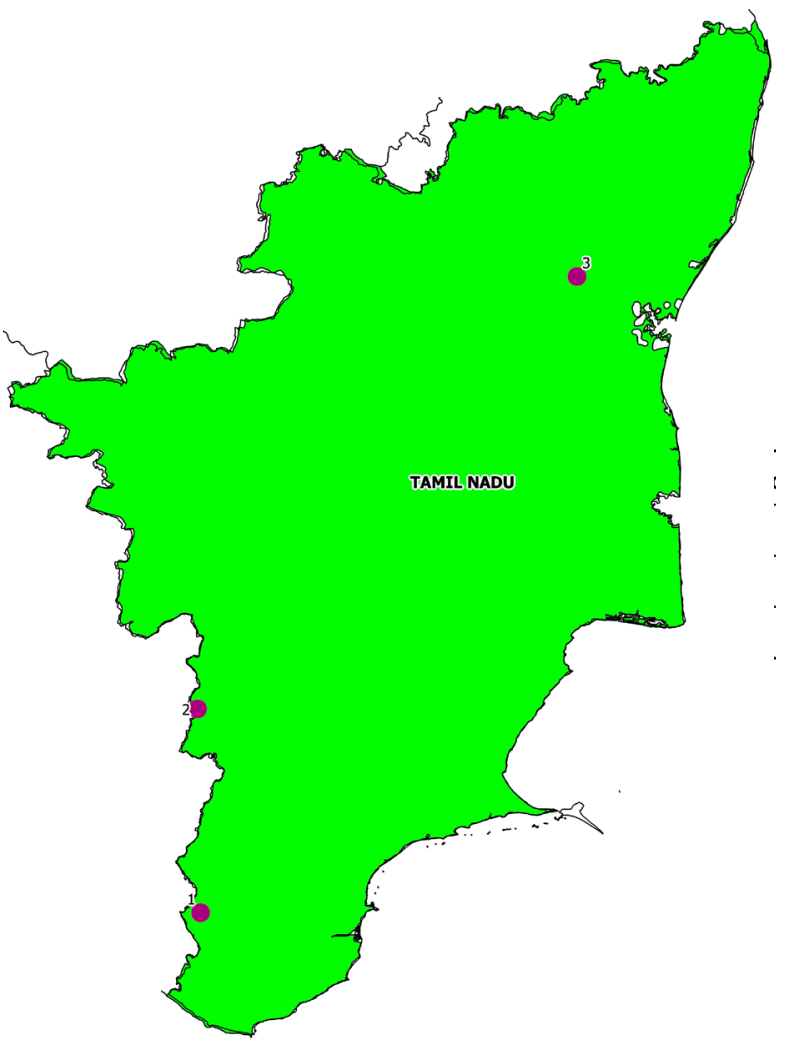

\begin{tabular}{|l|l|l|l|}
\hline SI no & State & Location & Altitude (m) \\
\hline 1 & Tamilnadu & Agasthya malai & 782 \\
\hline 2 & Tamilnadu & Theni & 672 \\
\hline 3 & Tamilnadu & Pakkamalai R.F & 360 \\
\hline
\end{tabular}

Figure 2. Distribution of Drypetes porteri

\section{Lamiaceae}

\section{Premna wightiana}

Schauer in A. DC., Prodr.11: 635. 1847; C.B. Clarke in Hook.f., Fl. Brit. India 4: 578. 1885; Gamble, Fl. Madras. 1096. 1924; A. Rajendran \& P. Daniel, Indian Verbenaceae: 291. 2002. Gumira wightiana (Schauer) Kuntze, Revis. Gen. PI. 2: 508. 1891. Premna thyrsoidea Wight, Icon. PI. Ind. Orient. 4(3): t. 1485. 1849; C.B. Clarke in Hook. f., Fl. Brit. India 4: 579. 1885. Gumira thyrsoidea (Wight) Kuntze, Revis. Gen. PI. 2: 508. 1891. (Image 3).

Straggling shrubs, 2-3 m high; branchlets slender, bark yellowish-brown with conspicuous lenticels. Leaves ovate-broadly ovate to elliptic, 5.5-11 x 3.0-6.7 $\mathrm{cm}$, usually entire to irregularly distantly serrate in upper half, mature leaf black when dry, young leaves sparsely pubescent, lateral nerves 4-6 pairs, obscure and impressed above, distinct and raised beneath; petioles canaliculated, pubescent above, opposite pairs unequal in length, $1.5-4.5 \mathrm{~cm}$ long. Inflorescence terminal, thyrses composed of opposite decussate cymes, 3-7 x 2-3, densely pubescent. Calyx cupular, distinctly 5 -toothed; teeth acute, pubescent outside. Corolla 2 lipped, 4 to 5-lobed, cream or greenish (in bud); lower lip 3-lobed; lobes subequal, densely villous at throat, puberulous outside. Stamens 4, didynamous, included. Stigma 2-lobed. Drupes obovoid, puberulous when young, shiny and black when ripe.

Specimen examined: 3825, Gangavaram, Pakkamalai RF, Gingee (in flower \& fruit), 350m, 01.x.2002, Paul Blanchflower; 3200, 08.viii.2001, Gangavaram, Pakkamalai RF, Gingee, $12^{\circ} 10^{\prime} \mathrm{N} \& 79^{\circ} 18^{\prime} \mathrm{E}, 350 \mathrm{~m}$, Paul Blanchflower (in flower \& fruit); F7964, 15.iii.2000, Gangavaram, Pakkamalai RF, Gingee (in flower bud), $12^{\circ} 10^{\prime} \mathrm{N} \& 79^{\circ} 18^{\prime} \mathrm{E}, 300 \mathrm{~m}$, Paul Blanchflower \& Walter F.

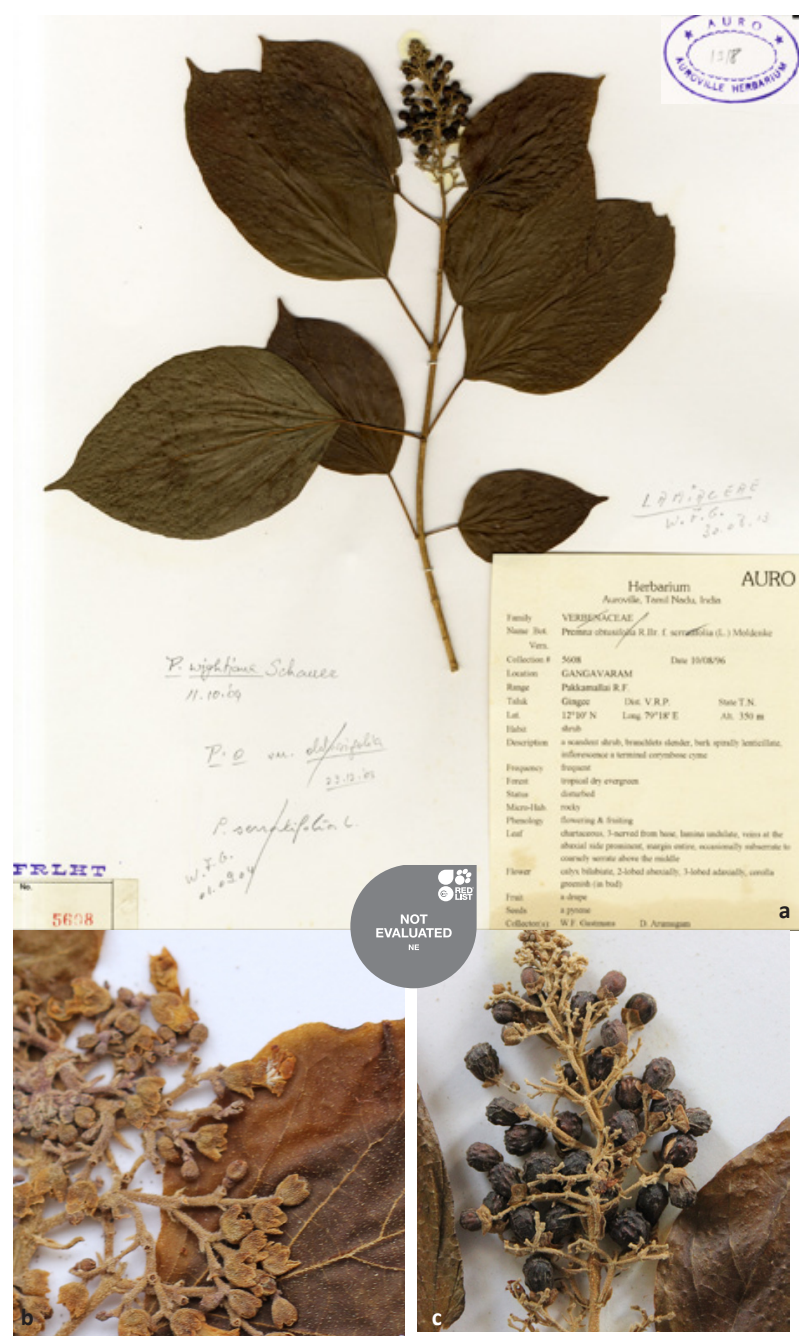

Image 3. Premna wightian a - Fruiting body; b - Flower, c - Fruit. 


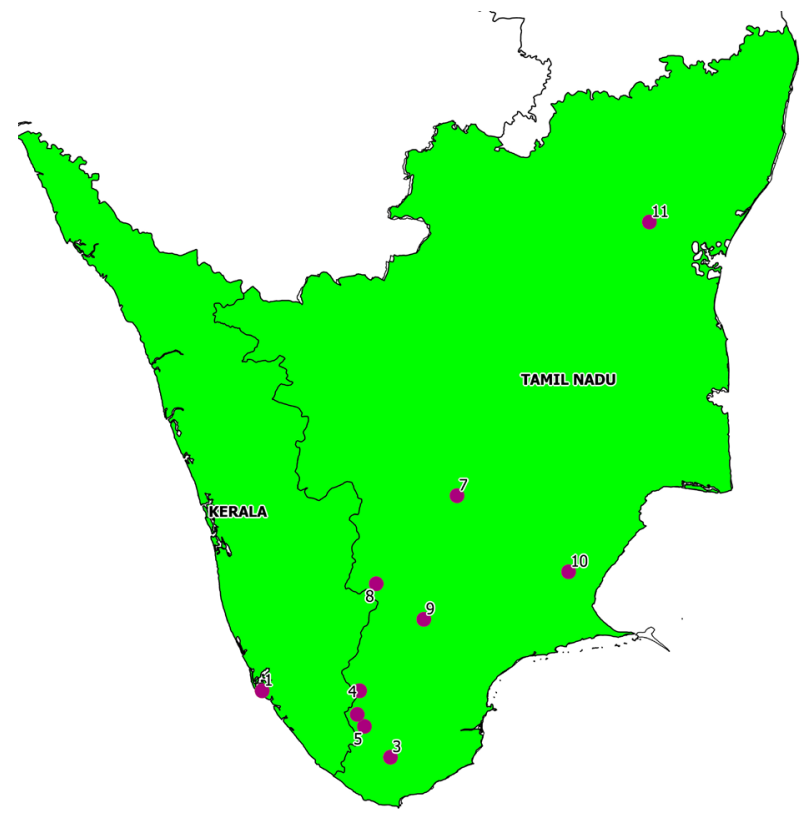

\begin{tabular}{|l|l|l|l|l|}
\hline SI. No. & State & District & Location & Altitude (m) \\
\hline 1 & Kerala & Quilon & side of canals & 8 \\
\hline 3 & Tamilnadu & Tirunelveli & Kalakkadu & 357 \\
\hline 4 & Tamilnadu & Tirunelveli & Courtallum & 785 \\
\hline 5 & Tamilnadu & Tirunelveli & Mundanthurai & 277 \\
\hline 6 & Tamilnadu & Tirunelveli & Papanasam & 515 \\
\hline 7 & Tamilnadu & Madurai & Sirumalai & 437 \\
\hline 8 & Tamilnadu & Madurai & High wavy mountain (mrf) & 1121 \\
\hline 9 & Tamilnadu & Ramanathapuram & Parapalar dam & 16 \\
\hline 10 & Tamilnadu & Ramanathapuram & Sethur hills & 23 \\
\hline 11 & Tamilnadu & Villupuram & Gingee hills & 360 \\
\hline
\end{tabular}

Figure 3. Distribution of Premna wightiana

Gastmans; 5608, 10.viii.1996, Gangavaram, Pakkamalai $\mathrm{RF}$, Gingee (in flower \&fruit), $12^{\circ} 10^{\prime} \mathrm{N} \& 79^{\circ} 18^{\prime} \mathrm{E}, 350 \mathrm{~m}$, coll. Walter F. Gastmans \& D. Arumugam.

Flowering \& Fruiting: August-February.

Ecology: Found as occasionally in scrub and deciduous forests, in rocky crevices and dry habitats. The species is found in association with Tarenna asiatica, Manilkara roxburghiana, Psilanthus wightianus and Pisonia aculeata.

Distribution: In India, this species was earlier known to occur in Western Ghats of Kerala and Tamil Nadu \& Eastern Ghats of Orissa. Latter, Daniel \& Rajendran (1993) recorded it from Sri Lanka.

Notes: The present collection from TDEF of Gingee Hills of southern Eastern Ghats shows the extended distribution.

\section{References}

Ahmedullah, M. \& P. Nayar (1986). Endemic Plants of the Indian Region. Vol. 1: 175. Botanical Survey of India, Calcutta.

Champion, H.G. \& S.K. Seth (1968). Revised survey of the forest types of India. Pp 397. Manager of Publications, New Delhi.

Daniel, P. \& A. Rajendran (1993). Premna wightiana Schauer, an addition to the flora of Sri Lanka. Sri Lanka Forester 19: 23-28.

Daniel, R.J.R., V.S. Ramachandran, J. Vencatesan, V. Ramakantha \& J.P. Puyravaud (2007). Dispelling the Myth of Tropical Dry Evergreen Forest of India. Current Science 92: 586-588.

Henry, A.N., G.R. Kumari, \& V. Chitra (1987). Flora of Tamil Nadu, India. Vol. 2. Botanical Survey of India, Coimbatore, 158pp.

Matthew, K.M. (1983). Flora of Tamilnadu Carnatic. Vol. 3. Rapinat Herbarium, Tiruchirapalli, pp. 689-1540.

Meher-Homji, V.M. (1974). On the origin of the tropical dry evergreen forest of south India. International Journal of Ecology and Environmental Science 1: 19-39.

Pullaiah, T. \& D.A. Moulali (1997). Flora of Andhra Pradesh. Vol. 2. Scientific Publishers, Jodhpur, pp. 465-912.

Saxena, H.O. \& M. Brahmam (1995). Flora of Orissa. Vol. 3. Orissa Forest Development Corporation Ltd., Bhubaneswar, pp. 14161422

Singh, V. (2005). Monograph on Indian Diospyros L. (Persimmon, Ebony) Ebenaceae. Botanical Survey of India, Kolkatta, 293pp.

Sprangers, J.T.C.M. \& K. Balasubramanian (1978). A phytosociological analysis of the tropical semi-evergreen forest of Marakkanam, south-east India. Tropical Ecology 19: 70-92.

Vijayasankar, R., K. Ravikumar \& P. Ravichandran (2012). Plant Resources of Tiruvannamalai District Tamilnadu, India.Bishen Singh Mahendra Pal Singh, Dehra Dun, 343pp. 